\title{
EVALUATION OF COASTAL RISK AT SELECTED SITES AGAINST EASTERN MEDITERRANEAN TSUNAMIS
}

\author{
A. C. Yalciner ${ }^{1}$, C. Ozer ${ }^{1}$, H. Karakus ${ }^{1}$, A. Zaytsev ${ }^{2}$, I. Guler ${ }^{1}$ \\ ${ }^{1}$ Middle East Technical University, Department of Civil Engineering, \\ Ocean Eng. Research Center, 06531 Ankara, Turkey \\ Phone: +90 312-2105438 Fax: +90 312-2101800 \\ yalciner@metu.edu.tr, cozer@metu.edu.tr, khulya@metu.edu.tr isikhan@metu.edu.tr \\ ${ }^{2}$ Special Research Bureau for Automation of Marine Researches, \\ Far Eastern Branch of Russian Academy of Sciences \\ 693013 Russia Uzhno-Sakhalinsk Gorkiy str. 25 \\ Phone: 7(42-42)55-49-66 Fax: 7(42-42)55-49-66 \\ aizaytsev@mail.ru
}

\begin{abstract}
Mediterranean, the center of civilizations since antiquity, experienced numerous earthquakes and triggered tsunamis. Historical information and distribution of fault zones, volcanoes and other probable tsunamigenic sea bottom deformations show that, there are source areas which may be considered as responsible for tsunamis in Eastern Mediterranean, Aegean, Marmara and Black sea region. These events affected the coastal structures that led to the loss of the economic power and social life of civilizations since antiquity. One of the probable examples of the earthquake or tsunami effects on the Fethiye town may be the eruption of Thera (also referred to as the Thera eruption or Santorini eruption). Another example of the earthquake or tsunami effects on the historical structures may be the destruction of lighthouse of Patara (Lykian City) harbor at the South of Turkey. The numerical modeling is one of the efficient tools for understanding the tsunami behaviors in the past. In this study, the historical data of earthquakes and tsunamis are evaluated together with the instrumental data of seismicity in order to select the tsunami source for modeling efforts. In modeling application, the most effective tsunami source among the others in Eastern Mediterranean is selected and simulated in order to better understand its possible effects on Fethiye town and the Patara (Lykian City). In this study, the simulation results are presented and dicussed for these selected regions.
\end{abstract}

Keyword: tsunami, Mediterranean, Patara, Fethiye, simulation, modeling

\section{INTRODUCTION}

The Mediterranean Sea is connected to the Atlantic Ocean surrounded by the Mediterranean region and enclosed by Anatolia and Europe on the North, North Africa on the South and Asia on the East. The Mediterranean Sea is $3900 \mathrm{~km}$ long and its maximum width is $1600 \mathrm{~km}$ and greatest depth is $4400 \mathrm{~m}$. It is one of the biggest marginal seas on the planet and located in between latitudes $30^{\circ} \mathrm{N}$ and $47^{\circ} \mathrm{N}$, and longitudes $-5^{\circ} \mathrm{W}$ and $43^{\circ} \mathrm{E}$. Sicily divides the sea into eastern and western basins. The Mediterranean Sea extends to the Aegean Sea and connects with the Black Sea through the Dardanelles; the Bosporus, and the Sea of Marmara; with the Atlantic Ocean through the Strait of Gibraltar; and with the Red Sea through the Suez Canal. Adriatic, Ionian and Tyrrhenian seas are its other main divisions. It covers an approximate area of 2.5 million $\mathrm{km}^{2}$. The Mediterranean Sea is well known and it is the center of attraction with its olive, grape, wine, date, breeze, clear waters, sun and remnants of ancient civilizations.

During the last 36 centuries, 67 earthquakes with the magnitude of greater than $7(\mathrm{Mw}>7), 133$ earthquakes with the magnitude between 6 and $7(7>\mathrm{Mw}>6)$ and at least 96 tsunamis were documented in the Eastern Mediterranean (Altınok and Ersoy 2000). The large scale earthquakes and associated tsunamis in region may be the reasons of the destructions at the coastal utilities of the ancient civilizations. Fethiye town is one of the attractive tourist destinations in Turkey and have effected by earthquakes and tsunamis in history (Minoura et al. 2000). Similarly, the ruins of lighthouse of the ancient Patara city warns the evidence of one of the recent findings in archaeological site $\left(29.2827^{\circ}\right.$ E $\left.36.2706^{\circ} \mathrm{N}\right)$ at Southwest of Turkey. These coastal areas were not so densely populated and utilized in the past when the tsunamis occurred. Therefore the information known on the effects of these tsunamis are limited only with the populations who experienced tsunami near the coasts however it is well known that the effects of these tsunamis were devastating. It can be expected that any future similar tsunami will be much more effective on the coasts. In order to protect coastal areas from catastrophic effects of tsunami, besides examining the archive information, it is also helpful to use simulation technique to understand the generation, propagation 
and coastal amplification of tsunamis and by using these information it is possible to take necessary precautions for the better preparedness against future events.

In this study, two regions are selected near SW coast of Anatolia as Fethiye and Patara for the assessment of possible effects of historical tsunamis by using tsunami numerical modeling. This paper outlines the simulation of a selected tsunami scenario in the region, and presents the level of inundation and coastal amplification on these coastal areas.

\section{THE STUDY AREA (FETHIYE AND PATARA) AND THE SEISMICITY IN THE REGION}

The general view of topography, bathymetry and epicenters of earthquakes happened in Eastern Mediterranean since 1900 are given in Figure 1 where the ellipses are located along the main fault zone in the Eastern Mediterranean near Fethiye and Patara regions.

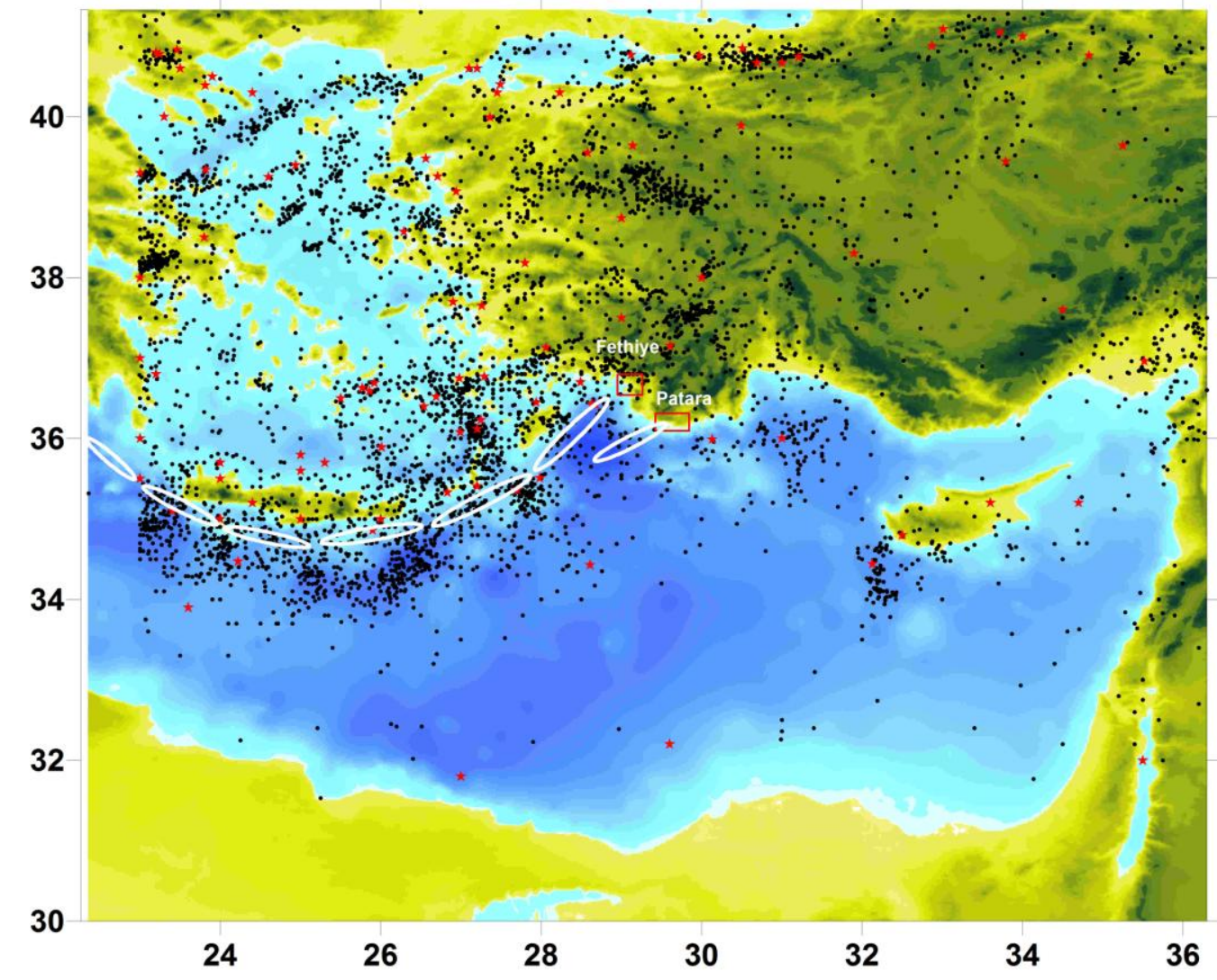

Figure 1: General view of topography and bathymetry of the Eastern Mediterranean Sea, distribution of earthquake epicenters since 1900 and main fault zones in Eastern Mediterranean region

In addition to the data obtained from the seismic records of epicenter locations, the historical documents also provide information about numerous large earthquakes and associated tsunamis in the Eastern Mediterranean region. Altinok and Ersoy (2000) and Doumas (1980 a,b), Hardy and Renfrew (1990a,b,c), Altinok et al.(2001) and Papadopoulos (2001) give the lists of tsunamis in Eastern Mediterranean. According to the historical data and distributions of the earthquake epicenters in Eastern Mediterranean, it is possible to estimate the tsunami prone areas in the Eastern Mediterranean. The brief history of these selected locations (Fethiye Bay and Patara town) and the effects of some historical tsunamis in these regions are given in the following section. 
Fethiye is located near the ancient city of Telmessos, the ruins of which can be seen in the city, e.g. the Hellenistic theatre by the main quay. The Minoan eruption of Thera was a major catastrophic volcanic eruption which is estimated to have occurred around 1630 B.C. (Hardy and Renfrew, 1990a,b,c). The eruption was one of the largest volcanic events on Earth in the recorded history. The generation mechanism and coastal effects of associated tsunamis in the region have not been identified yet. However the tsunami deposits suggesting the sea water inundation related to Thera eruption are found at the sites, Crete near Gouves and Anatolia near Didim, Fethiye. (Minoura et al. 2000). Geological, archaeological and radiocarbon dating criteria made on these regions indicate that the tsunami deposits are coeval with the Minoan Santorini eruption (Bruins et al, 2008, Minoura et al. 2000). Significant stratified findings are from Didim and Fethiye in south-western Turkey where $10 \mathrm{~cm}$ thick sandy layer, interpreted as tsunamigenic, underlies Minoan Santorini tephra (Minoura et al., 2000).

Patara beach is one of the most popular beaches of the eastern Mediterranean at southern Turkey with the length of about $12.3 \mathrm{~km}$. The city Patara is known as the largest and most important harbor in the ancient Lycian civilization and this harbor was still active as a small estuary till the end of XVth century. Archaeologists claim that an ancient lighthouse located in the ancient city of Patara on Antalya's Mediterranean coast might have been destroyed by a tsunami that hit the region in ancient times (Isik-İskan, 2008).

The location of Fethiye and Patara regions in Eastern Mediterranean and the simulation area together with the selected tsunami source are shown in Figure 2.

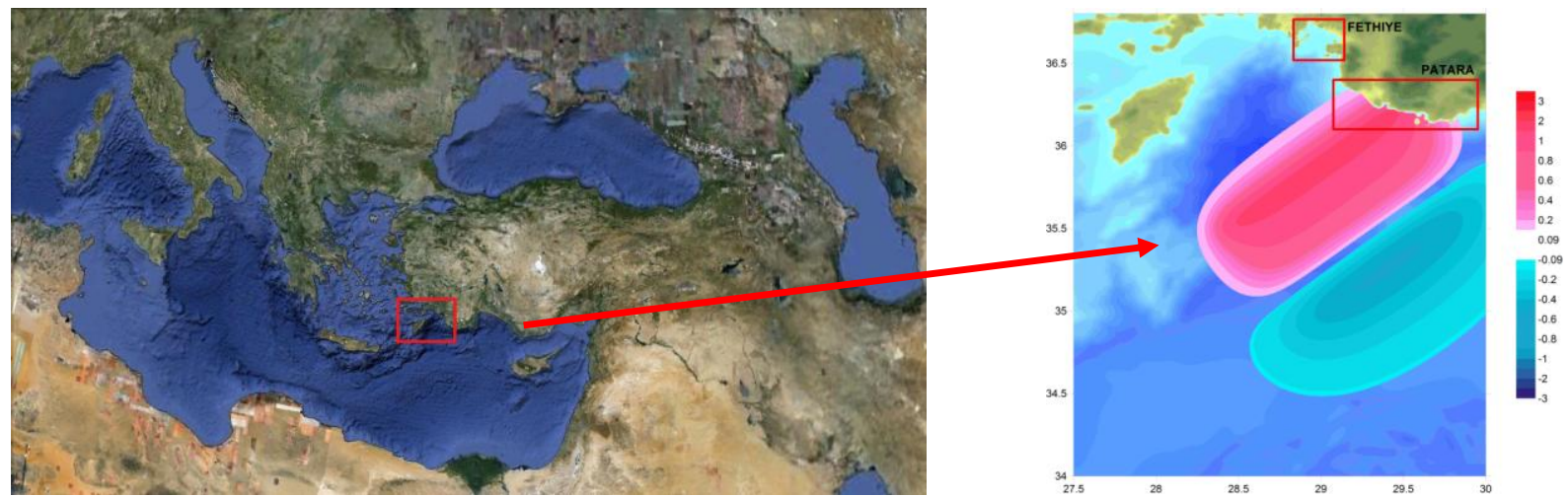

Figure 2: The location of study domain, Fethiye and Patara Region, in Turkey and tsunami source of the numerical modeling

\section{TSUNAMI MODELLING IN EASTERN MEDITERRANEAN FOR FETHIYE AND PATARA TOWNS}

Modeling is one of the most essential tools and it is necessary to assess, examine, discuss and develop proper tsunami mitigation measures for the better preparedness against future events. Tsunami modeling covers i) mathematical description of the problem and initial/boundary conditions with proper approximations and assumptions, ii) solutions of the governing equations with different techniques, iii) simulation, and iv) visualization. Beyond these, the other important issues of tsunami modeling are; v) analysis of the results, vi) interpretation of the results and tsunami parameters, vii) understanding of their effects in the inundation zone, and viii) developing the mitigation measures accordingly and viii) using them for educational and public awareness purposes.

In order to define the probable effects of tsunamis at target areas (Fethiye and Patara), the coastal topography are taken into consideration. Using different approaches and their results on arrival time, maximum positive amplitudes near shoreline, flow depth in inundation zone, shoreline velocities and estimated runup and inundation distances, and the potential effects of probable tsunamis should be computed for the assessment of coastal risk against tsunamis (Yalciner et al., 2006a). 
These parameters are related to the characteristics of the tsunami source. Tsunami source means the area of tsunami origin, usually the site of an earthquake, volcanic eruption, or landslide that caused large-scale rapid displacement of the water to initiate the tsunami waves. Several parameters describe a tsunami source commonly used for tsunami simulations; epicenter of the fault axis, length and width of the fault, strike, dip and slip angles, focal depth etc.

Since historical data about the seismicity are not available for most of the coastal areas, the exact location of the sources is seldom known accurately. Thus, the tsunami sources are estimated as rupture specific scenarios. Characteristics, dimensions and locations of near field and far field submarine and/or coastal faults and other tsunami prone regions can be defined by i) characterization of tsunami faults, ii) identification of unstable bodies, submarine landslides and possible tsunamigenic seafloor deformations. This is quite a tough task that needs much discussion among scientists from different disciplines, since uncertainties in the underlying fault rupture and landslide processes are high.

The tsunami source mechanism for the Fethiye and Patara region to be used in numerical modeling was selected from the fault parameters of several scenarios which were obtained from the outcomes of EUfunded TRANSFER Project. Since there is no sufficient information available about source parameters of the earthquakes in the region, the dip and slip angle of the faults are justified to give worst case conditions of tsunami sources. According to the worst case scenario for Fethiye and Patara region, the epicenter of fault is assumed to be located at $28.4^{\circ} \mathrm{E}$ and $35.5^{\circ} \mathrm{N}$ with the length of $140 \mathrm{~km}$ and the width of $70 \mathrm{~km}$. the focal depth is $10 \mathrm{~km}$ and the displacement is $4 \mathrm{~m}$. The strike, dip and rake angles in the analyses are used as $55^{\circ}$ (clockwise from north), $20^{\circ}$ and $90^{\circ}$, respectively.

The tsunami source used in the numerical modeling for Fethiye and Patara regions is given in Figure 2. The initial maximum positive wave amplitude at the source is $1.8 \mathrm{~m}$ and maximum negative wave amplitude is $-0.5 \mathrm{~m}$.

\section{TSUNAMI SIMULATIONS AND RESULTS}

Numerical modelling is one of the efficient tools to estimate the tsunami propagation and the related coastal risk. In this study the tsunami numerical modeling NAMI DANCE is used for simulating the possible worst case tsunami scenario effecting Fethiye and Patara regions in the Eastern Mediterranean. The model solves nonlinear form of shallow water equations (NLSW) using finite difference solution technique (Shuto et al, 1990) and it computes the propagation and coastal amplification of tsunami waves according to the initial tsunami source generated by earthquake rupture parameters or other types of mechanisms in the nested computation domains simultaneously. The nested domains of Fethiye and Patara regions are produced as Domain B, C, D and E with the grid sizes of $405 \mathrm{~m}, 135 \mathrm{~m}, 45 \mathrm{~m}$ and $15 \mathrm{~m}$, respectively. The nested domains of $\mathrm{C}, \mathrm{D}$ and $\mathrm{E}$ in the largest domain $\mathrm{B}$ in Fethiye and Patara region are shown in Figure 3. Domain C Fethiye covers Fethiye region, Domain E Fethiye covers Fethiye Bay, Domain C Patara covers Patara Region and Domain E Patara covers Patara town (Figure 3).

The simulation duration is taken as 150 min of real-time computation in nested Domains B, C, D and E. This duration is sufficient to see the maximum effect of the probable tsunamis in the Fethiye and Patara regions with the selected tsunami scenario. Time histories of water surface oscillations and the distribution of maximum water surface elevations in the study domains during simulation duration are determined and plotted.

Figure 4 gives the time histories of water level fluctuations at the selected gauge points and maximum water surface elevations during simulation duration near Fethiye Region. The simulation results show that the wave arrives Fethiye bay (Domain E Fethiye) in 20 minutes after its generation with the amplitude above $4 \mathrm{~m}$ near the entrance of Fethiye Bay and $2 \mathrm{~m}$ inside Fethiye Bay. It is seen from the Figure $4 \overline{;}$ the waves reach the amplitude of $3 \mathrm{~m}$ at north of Fethiye Region (Gocek town at North of- Domain C Fethiye) with the arrival time of 15 minutes. 


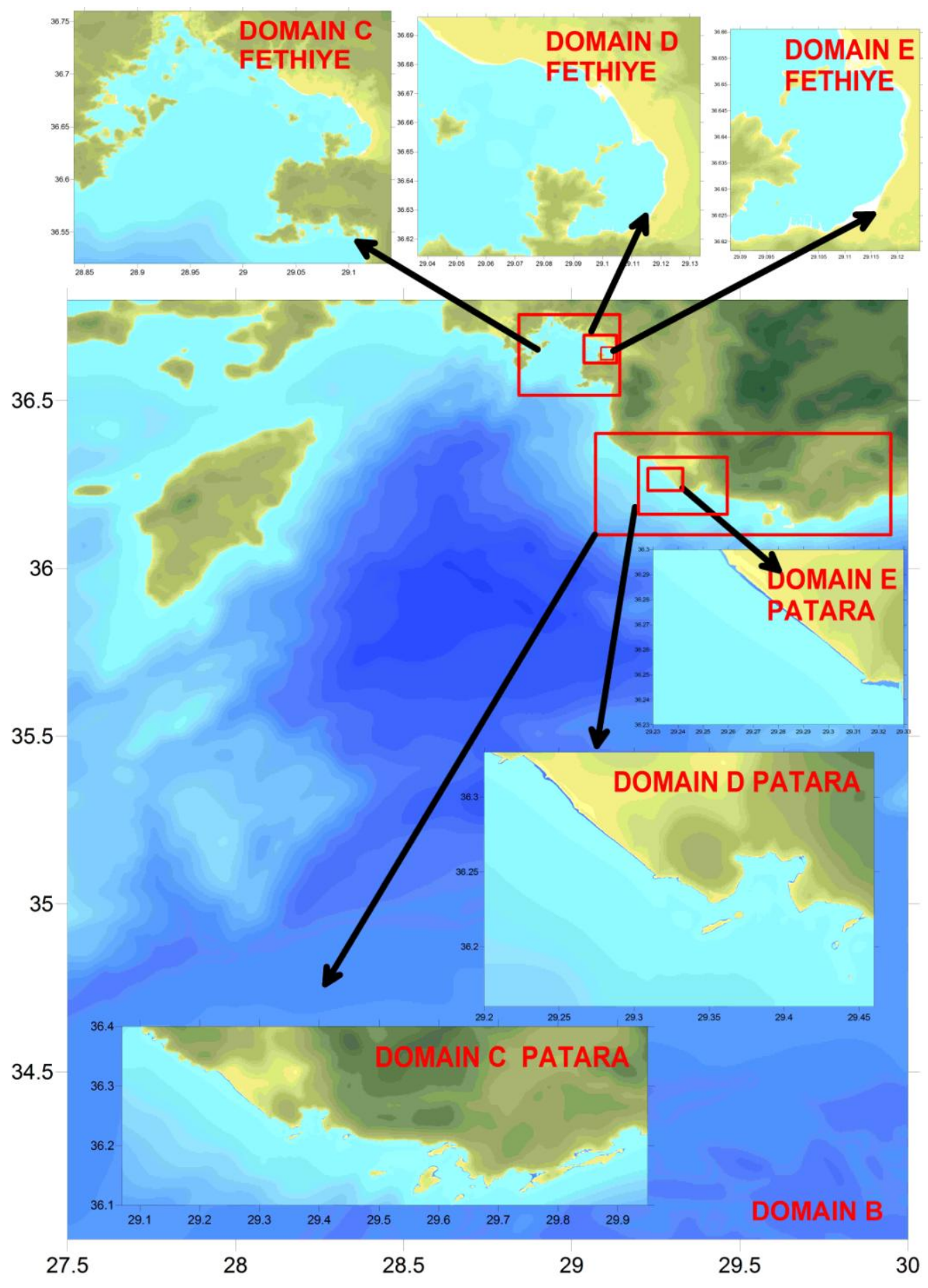

Figure 3: Nested domains of B, C, D and E for Fethiye and Patara Regions 


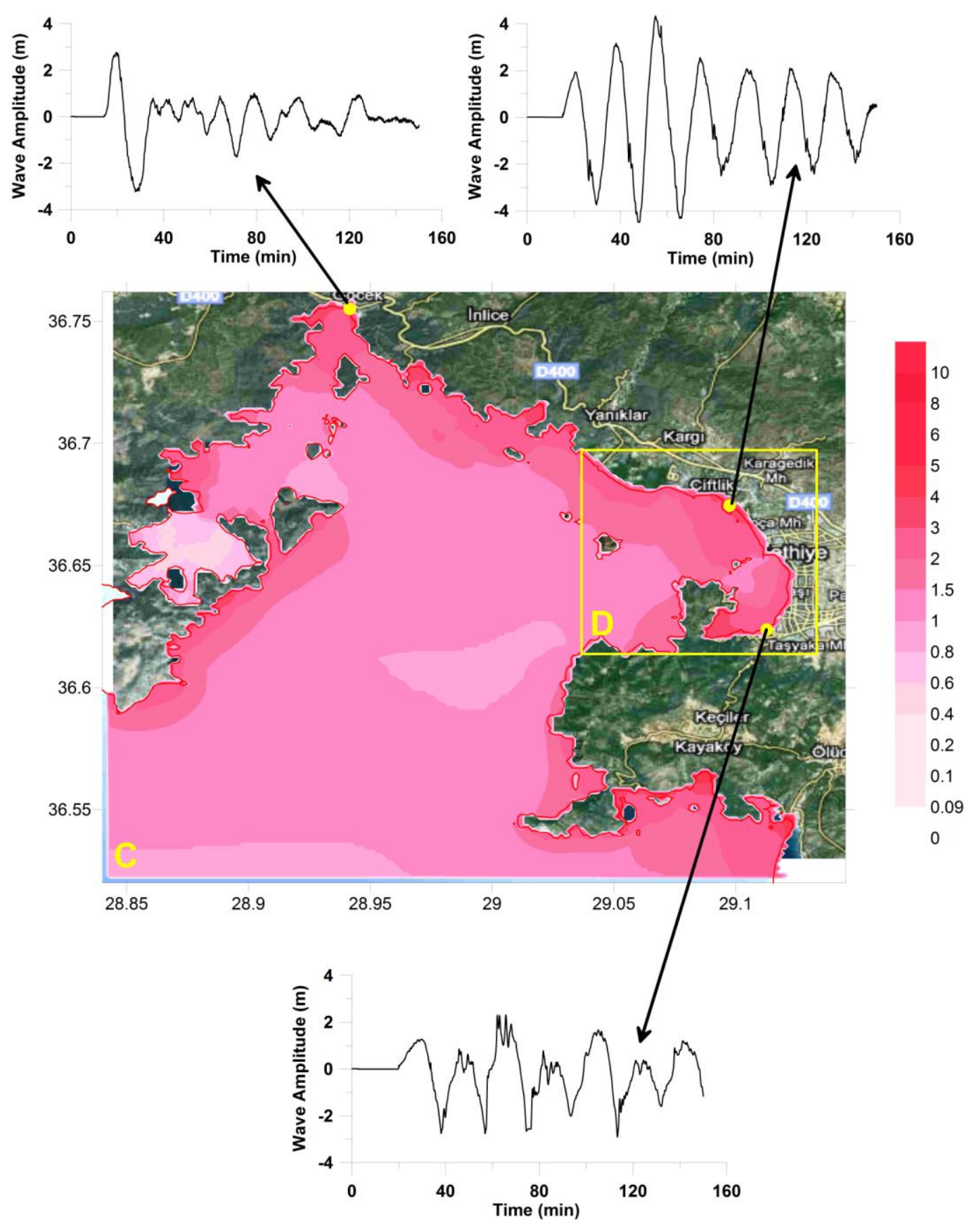

Figure 4: Time histories of water Surface Fluctuations at selected gauge points near Fethiye

Figure 5 shows the inundation areas near Fethiye Bay according to the simulated tsunami source. It can be seen from the Figure 5 that the simulated tsunami waves can be more affected outside Fethiye Bay.

Figure 6 shows the time histories of water level fluctuations at the selected gauge points and maximum water surface elevations during simulation near Patara region. The simulation results show that the wave amplitude reaches up to $6 \mathrm{~m}$ near Patara region. 


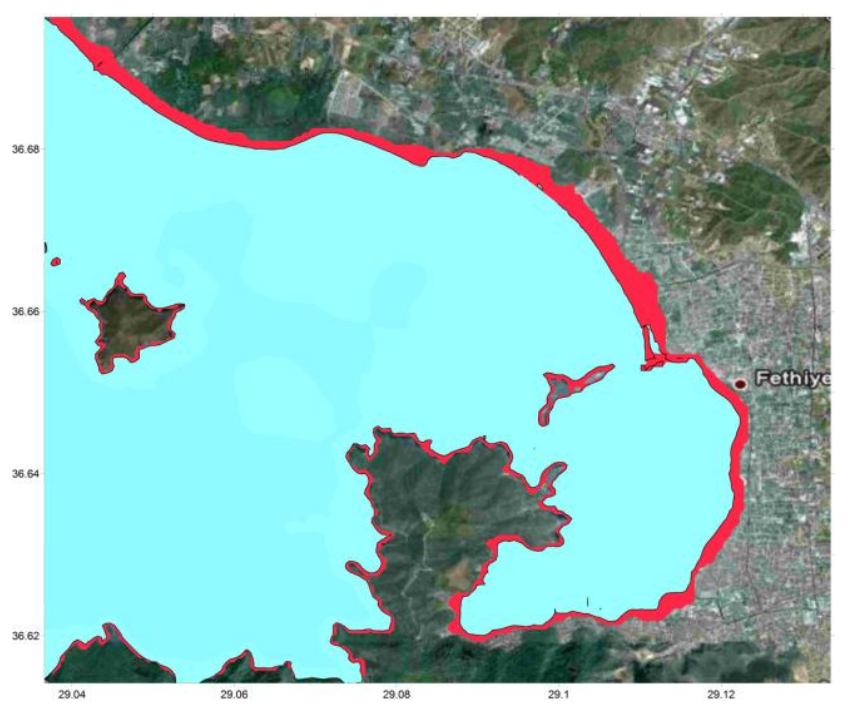

Figure 5: The inundation areas near Fethiye according to the simulated tsunami source

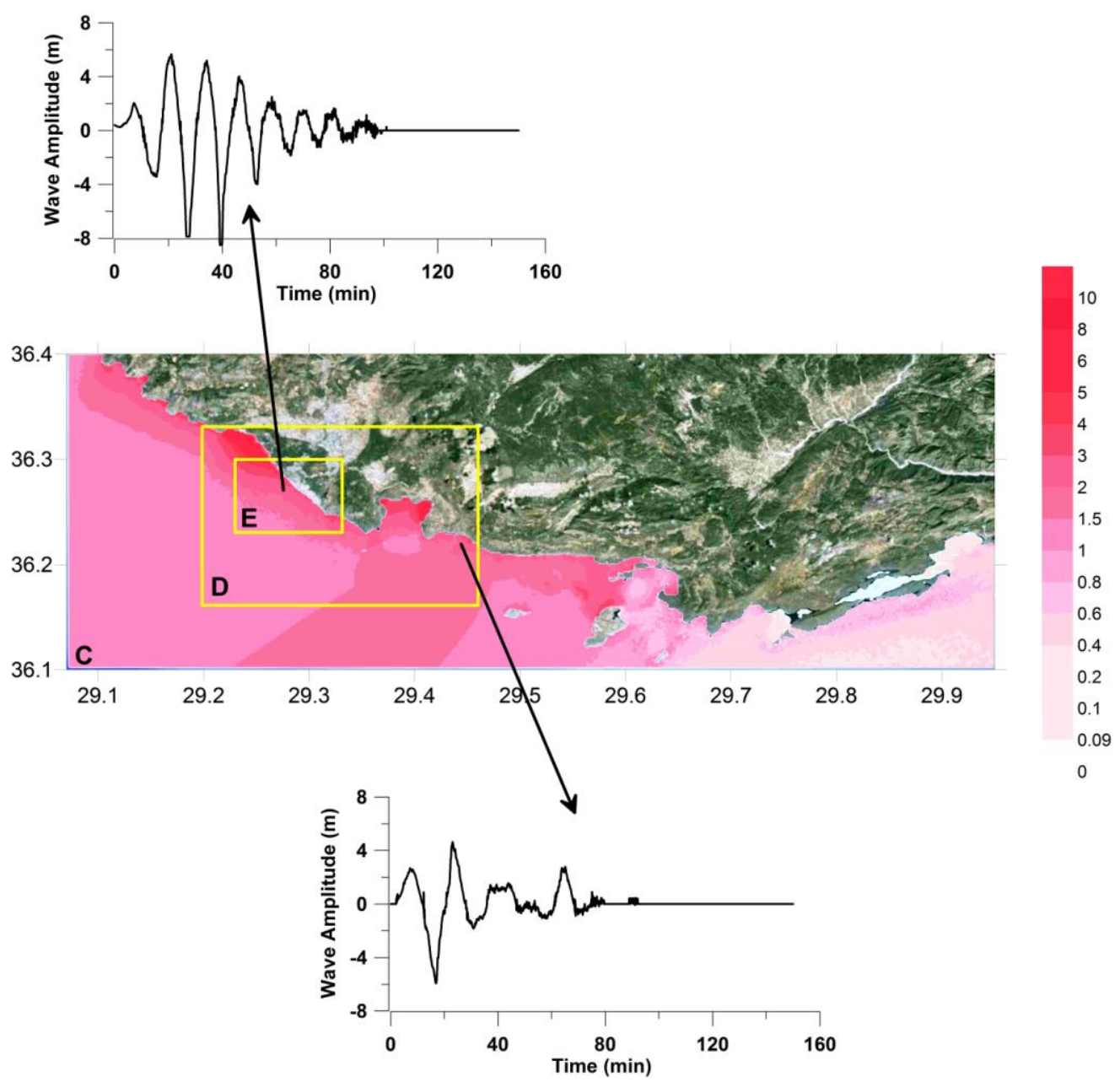

Figure 6: Time histories of water surface fluctuations at the selected gauge points near Patara region 
Figure 7 shows the inundation areas near Patara region according to the simulated tsunami source. It can be seen from the Figure 7 that the simulated tsunami waves cannot penetrate much distance at land near Patara region to cause destruction on the Patara lighthouse.

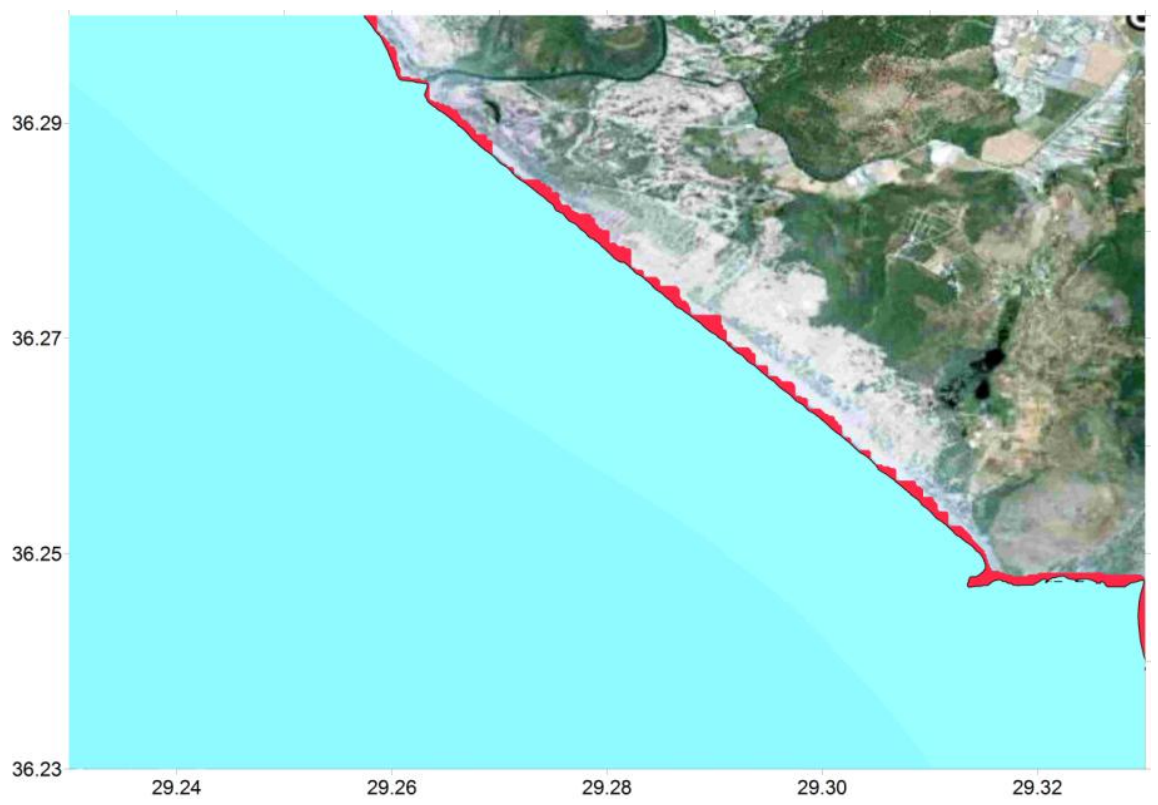

Figure 7: The inundation areas near Patara according to the simulated tsunami source

\section{CONCLUSION}

One of the aims of these simulations is to produce the inundation maps showing the information of the estimated hazard zone parameters such as design flow elevation (DFE), arrival time and maximum current velocity. These maps also give comparisons of the estimates between different scenario events and their risk on the coastal zone.

The propagation, possible coastal amplifications and the level of coastal effects of a selected tsunami are investigated by focusing of the selected two coastal areas in the region considering an ancient settlement (ancient city of Patara) and present settlement (Fethiye bay). According to the simulation results, it is seen that the tsunami amplitudes Fethiye bay can reach $4 \mathrm{~m}$ and near Patara region can reach $6 \mathrm{~m}$. There still are more efforts necessary to determine the reason of destruction of Patara Lighthouse.

\section{ACKNOWLEDGEMENTS}

The authors thank Profs E. Pelinovsky, A. Chernov and A. Kurkin for their collaboration and efforts in development of the tsunami code NAMI DANCE. This study is partly supported by European Union Projects TRANSFER (Tsunami Risk and Strategies for the European Region) supported by the CEC, contract n. 037058, FP6-2005-Global-4, and also Fethiye Municipality. This study is partly supported by TUBITAK 108Y227 Turkish Russia Joint Research Project Grant. The authors also thank Profs. Nobuo Shuto and Fumihiko Imamura for their authorship of tsunami code TUNAMI N2 and N3 which provided the basic routines to NAMI DANCE.

\section{REFERENCES}

Altinok, Y., Ersoy, Ş., Yalciner, A. C., Alpar B., and Kuran, U., (2001), " Historical tsunamis in the Sea of Marmara, International Tsunami Symposium 2001, Seattle 
Altinok, Y. and Ersoy, S., (2000), Tsunamis observed on and near Turkish Coasts, Kluwer Academic Publishers, Journal of Natural Hazards Vol. pp 185-199, 2000

Altinok, Y., Ersoy, Ş., Yalciner, A. C., Alpar B., Kuran U., (2001) "Historical tsunamis in the Sea of Marmara", International Tsunami Symposium ITS 2001, Session 4, Paper 4-2, Seattle, August 7-9, 2001, pp: 527-535

Bruins H,J., MacGillivray J. A., b,. Synolakis C. E., Benjamini C., Keller J., Kisch H.J., (2008), "Geoarchaeological tsunami deposits at Palaikastro (Crete) and the Late Minoan IA eruption of Santorini”, Journal of Archaeological Science 35 (2008) pp: 191-212

Dilmen, D.I., (2008), "GIS Based tsunami inundation maps; case studies from Mediterranean" 149 pages, Master Thesis

Doumas C., (1980a), Thera and the Aegean World', ISBN 09560613334 Vol.1

Doumas C., (1980b), Thera and the Aegean World', ISBN 09560613339 Vol.2

Hardy D. A. ve Renfrew A. C., (1990a), "Thera and the Aegean World Archaeology", Proceedings of Third International Congress Santorini, Greece, September, 3-9, 1989, Vol. 1

Hardy D. A. ve Renfrew A. C., (1990b), "Thera and the Aegean World Earth Sciences", Proceedings of Third International Congress Santorini, Greece, September, 3-9, 1989, Vol. 2

Hardy D. A. ve Renfrew A. C., (1990c), "Thera and the Aegean World Chronology", Proceedings of Third International Congress Santorini, Greece, September, 3-9, 1989, V 3

Işık-İșkan, H., (2008), "Patara'dan bir Demos Kabartması", Prof. Dr. Haluk Abbasoğlu'na 65. Yaş Armağanı EUERGETES, pp: 639-648.

KOERI (2004), "Earthquake database of Bosphorus University, Kandilli Observatory and Earthquake Research Institute (KOERI), The link of Earthquake Database http://www.koeri.boun.edu.tr/jeofizik/defaulteng.htm

Minoura, K., Imamura, F., Kuran, U., Nakamura, T., Papadopoulos, G., Takahashi, T., Yalciner, A. C., (2000): Discovery of Minoan Tsunami Deposits, v. 28, no. 1, p.p: 59-62, January 2000.

Shuto,N., Goto, C. and Imamura, F., (1990): Numerical Simulation as a Means of Warning for Near-Field Tsunami, Coastal Engng in Japan, Vol.33 No.2, pp.173-193.

Yalciner, A.C., Karakus, H., Kuran, U., (2006A): Modeling of Tsunamis in the Eastern Mediterranean and Comparison with Caribbean, Caribbean Tsunami Hazard, World Scientific, Eds: Mercado A. And Liu P. L. F., ISBN 981-256-535-3, pp 326-340

Yalciner, A. C., Pelinovsky, E., Zaytsev, A., Chernov, A., Kurkin, A., Ozer, C., Karakus, H., (2006b): NAMI DANCE Manual, METU, Civil Engineering Department, Ocean Engineering Research Center, Ankara, Turkey (http://namidance.ce.metu.edu.tr 